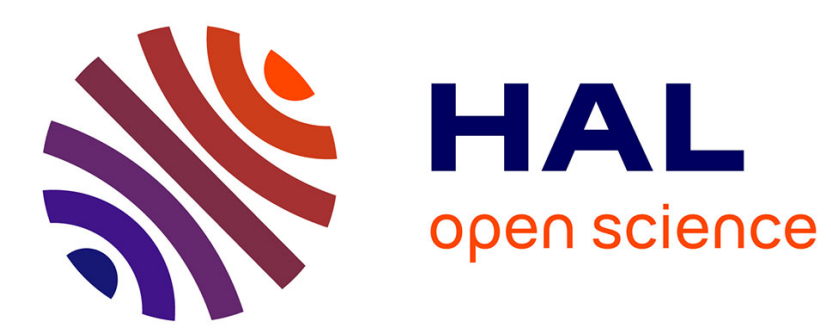

\title{
Red cell groups and Basque population(s): From anthropology to public health
}

Frédéric Bauduer

\section{To cite this version:}

Frédéric Bauduer. Red cell groups and Basque population(s): From anthropology to public health. Transfusion Clinique et Biologique, 2019, 26, pp.69 - 75. 10.1016/j.tracli.2018.11.002 . hal-03486256

\section{HAL Id: hal-03486256 \\ https://hal.science/hal-03486256}

Submitted on 20 Dec 2021

HAL is a multi-disciplinary open access archive for the deposit and dissemination of scientific research documents, whether they are published or not. The documents may come from teaching and research institutions in France or abroad, or from public or private research centers.
L'archive ouverte pluridisciplinaire HAL, est destinée au dépôt et à la diffusion de documents scientifiques de niveau recherche, publiés ou non, émanant des établissements d'enseignement et de recherche français ou étrangers, des laboratoires publics ou privés.

\section{다)(1) $(5$}

Distributed under a Creative Commons Attribution - NonCommerciall 4.0 International 


\section{Red cell groups and Basque population(s): from anthropology to public health}

Groupes sanguins érythrocytaires et population(s) basque(s) : de l'anthropologie à la santé publique

Frédéric Bauduer ${ }^{1,2}$

Professeur des Universités, Praticien hospitalier

${ }^{1}$ : Laboratoire PACEA, UMR CNRS 5199, Université de Bordeaux, 33600 Pessac

2: Service d'Hématologie, Centre hospitalier de la Côte basque, 13 Avenue de l'interne Jacques Loëb, 64100 Bayonne

Tél. : 0559443832 / Fax : 0559443837 / e-mail : frederic.bauduer@u-bordeaux.fr 


\begin{abstract}
The particular distribution of blood groups in Basques was initially described during the first half of the $20^{\text {th }}$ century especially regarding the $\mathrm{ABO}$ and Rhesus systems. We report herein the largest synthesis published so far on the distribution of blood groups in this population using serological or molecular methods. These characteristics are to be discussed in the light of evolutive forces acting in population genetics i.e drift, peopling history and natural selection. The basque population is of very ancient descent, has remained relatively unmixed through the ages and demonstrates some degree of heterogeneity. The possible impact of this hemotypology profile for public health is also discussed here.
\end{abstract}

Keywords : blood groups, Basques, anthropology, population genetics

\title{
Résumé
}

Les particularités de distribution des groupes sanguins chez les Basques ont été mises en évidence dès la première moitié du $20^{\text {ème }}$ siècle en ce qui concerne en particulier les systèmes $\mathrm{ABO}$ et Rhésus. Nous rapportons ici la plus large synthèse publiée à ce jour sur la distribution des groupes sanguins au sein de cette population étudiée par techniques sérologique ou moléculaire. Ces caractéristiques singulières sont à discuter selon les grandes forces évolutives agissant en génétique des populations à savoir la dérive génétique, l'histoire du peuplement et la sélection naturelle. La population basque est d'individualisation très ancienne, a subi relativement peu de mélanges génétiques et présente un certain degré d'hétérogénéité. L’impact possible de ce profil hémotypologique particulier au niveau de la santé publique est également discuté.

Mots clés : groupes sanguins, Basques, anthropologie, génétique des populations 
The Basques live currently within a zone located at the occidental extremity of Pyrenees including in the north, provinces of Labourd, Basse-Navarre and Soule in France (Iparralde) which are part of the département des Pyrénées Atlantiques, and in the south, within the Spanish territory (Hegoalde), provinces of Guipuzcoa, Navarre, Biscaye and Alava (fig. 1). Their original tongue (Euskara) is not a member of the indoeuropean family and its origin remains undetermined so far [1]. In the Basque area there are many prehistoric sites, some with cave paintings, which argue in favor of human presence from the upper paleolithic period. The Basques represent a population of interest for researchers for several decades. At the end of the $19^{\text {th }}$ century, anthropologists who studied their skulls and anthropometric characteristics considered that they were an autochthonous and very ancient "race" [2]. The ABO system was the first biological trait explored for studying human polymorphism a century ago. Thus, in 1919 (the period of scientific racialism supporting the views of European nationalisms including the German Nazi party), was published the first paper reporting the $\mathrm{ABO}$ profile within a sample of soldiers from different origins collected in Salonica (Greece) [3]. In France, Jacques Ruffié, in association with Jean Bernard, was a pioneer of « hemotypology» and replaced the concept of « race » by that of «population» [4]. These two renowned researchers initiated fertile connections between hematology and anthropology. As other genetic characteristics, the distribution of blood group systems is dependent upon three main evolutional mechanisms which are drift, peopling history (i.e migration and mixing) and natural selection [1]. The Basques being a very ancient human group in Europe, they demonstrate particular patterns with regards to culture and genetics [1]. In the field of biological anthropology, the study of blood groups has been replaced by more performant molecular markers over the past twenty years especially at the level of the $\mathrm{Y}$ chromosome or mitochondrial DNA. The uncommon distribution of blood groups in Basques has been reported in many publications but we present here for the first time the actualized 
data on a large number of systems including the latter results obtained by molecular typing methods (especially using PCR). Furthermore, we will address the possible impact of this profile regarding the role of blood groups in the propensity of developing specific diseases or the maternal fetal Rh immunization problem. When performing such a literature review one must keep in mind three main limitations: variable (and often not mentioned) criteria for defining an individual as Basque, the possible lack of performance of serological methods in the oldest studies and the existence of genetic heterogeneity within this population explaining the existence of subgroups in relation with history. In addition, as observed today in the majority of the western world, there is an increased tendency of mixing in the Basque Country which induces a progressive disappearance of these genetic particularities. The current ISBT 128 criteria will be used here for blood groups denomination.

\section{Distribution of blood group systems in the Basques}

\section{ABO System (table 1)}

The high frequency of group $\mathrm{O}$ and in the other hand the low existence of $\mathrm{B}$ in comparison with other European populations was first evidenced in 1937 in Basques from Hegoalde on a sample of 229 individuals living in the area of Saint-Sébastien, Guipuzcoa [5]. These characteristics were also found in French Basques and, at a lesser extent, in their neighbors living within the "Aquitany perimeter" [6]. The frequency of group $\mathrm{O}$ among Basques is comparable with that seen in several island populations as Ireland, Sardinia or Corsica [7]. The Basques express the lowest presence of group B in Europe with Corsicans and some limited zones as Ladine valley (northeastern Italy), populations from Caucase and Laplanders [7]. In addition to $\mathrm{O}$ predominance over $\mathrm{A}$, one should note that the proportion of $\mathrm{A} 2$ is inferior to that observed in other European regions [8]. The main "historical" studies on the distribution of the ABO system in Basques and their results are presented on table 1. 


\section{Rh system (tables 2 et 3 )}

The seminal work published in 1945 from a sample of Basque emigrants in Argentina evidenced a prevalence of RH :-1 (Rh-negative) phenotype at 35.6\% i.e an allelic frequency of 0.59 [9]. The subsequent studies failed to match this very high rate (mean frequency of RH:-1 phenotype at about 25\%) (table 2). Thus, for explaining this fact, one should evoke the lack of sensitivity of the anti-RH:1 (anti-D) antiserums used at that time or the existence of a sampling bias [10]. The Basques express actually one of the most elevated percentage of RH :-1 among all the human groups and, as Mourant stated, «their frequency of the $\mathrm{d}$ allele exceeds that of $\mathrm{D} »[7]$. Nevertheless they are not the absolute world champions of the RH:-1 expression; this phenotype is seen for instance in about $29 \%$ of individuals from Moroccan high-Atlas [11] or a zone in Saoudian Arabia [12]. Using molecular biology technology, Basques demonstrate the highest frequency of the haplotype RH:-1, RH:-2, RH:-3, RH:4, RH:5 (previously quoted as $c d e$ ) [13] and on the other hand one of the weakest of RH:-1, RH:2, RH:-3, RH:-4, RH:5 (dec), RH:-1,RH:-2, RH:3, RH:4, RH:-5 (dEc) and RH:1, RH:-2, RH:-3, RH:4, RH:5 (Dec) [10] (table 3). These findings had been already noted more than a half-century ago by serology [14].

\section{Other systems}

In the 1970's the American anthropologist Morton Levine had investigated nearly all the inhabitants of two small villages of the Labourd province, Ahetze (333 samples) and Macaye (399) with the help of the centre de transfusion sanguine of Biarritz directed by Henri Darrasse at that time [8]. In addition to the well-known characteristics of Basques regarding $\mathrm{ABO}$ and Rh systems he pointed out the lowest European prevalence of the FY :1 phenotype (Duffy system, about 32\% versus $65 \%$ in the British Isles for instance) and the highest frequency of K:1 (Kell system). The Basques express the lowest FY:1/FY:2 ratio among 
European populations [15]. Then, they have conserved a marked rate of the ancestral allele FY :2 [16]. The distribution of MN, P and Lutheran systems is comparable to that of the other occidental European populations [7]. MS is at its highest in Basques and conversely Ns at its lowest [8]. DO :1 (Dombrock system) and CO :1 (Colton system) seem to be less present than in other parts of Europe [17]. In contrast, there are no significant differences when exploring P [8], Kidd or YT (Cartwright) [17] systems.

\section{How explaining this particular hemotypology profile in terms of anthropology?}

The distribution of genetic characters within human populations is dependent upon the conjunction of several evolutionary forces: drift (effect of chance on small-size and isolated populations evolving over long periods of time which decreases genetic variability with some alleles disappearing and others becoming fixed), mixing between populations (genetic flow) and natural selection [1].

Moulinier [18] (who became later director of the centre de transfusion sanguine of Bordeaux) and also Ruffié [19] (founder of the centre d'hémotypologie of Toulouse) had shown than Basques shared their $\mathrm{ABO}$ and $\mathrm{Rh}$ (at a lesser extent) characteristics with their close Gascon neighbors from Bearn and also Bigorre supporting the hypothesis of a common ancestry before the Roman conquest. This ancestral group was subsequently divided in two peoples according to the occurrence of acculturation (conversion to a Latin-derived language or conservation of Euskara). The trace of this (these) Aquitanian people(s) anterior to the arrival of Romans may be evoked following two particular biocultural parallelisms. Interestingly, in this zone (grosso modo between the Atlantic Ocean, the Pyrenees and the Adour river) in which one can observe the maximal frequency of the $\mathrm{O}$ allele of southwestern France $(>73$ $\%$ ), existed a traditional system of inheritance law: the so-called "full (whatever the sex) birthright". In this same area, there is a significant concentration of pre-Roman toponyms 
deriving from ancestral Euskara (place names ending in -os, -ost, -ous) in contrast to the rest of southwestern France where are present toponyms of Latin origin (place names ending in ac) [20]. Furthermore, this marked prevalence of group O may be related to selective pressure (exposure to infectious agents?) and to drift [21]. The very limited expression of group B could be attributed to drift and to insignificant mixing with invading populations coming from Asia (who express high levels of B) after the fall of the Roman empire [1].

The elevated expression of $\mathrm{RH}:-1$ could represent an ancestral character of European populations prior to the advent of the Neolithic incomers from Middle-East [1,9]. There is actually a negative $\mathrm{RH}:-1$ gradient from Basque Country to the zone of agriculture emergence [1]. This pattern persisted through the ages because of endogamy and drift. The deletion of $R H: 1$ allele is the molecular event at the origin of the $\mathrm{RH}:-1$ phenotype in Europeans [13]. No evidence of positive selection around this allele has been shown so far [22]. This absence of selective pressure is especially seen in populations expressing a deletion frequency around 0.5 [22], which is the case of Basques. Recently, haplotype analyses of $\mathrm{RH}: 1 / \mathrm{RH}:-1, \mathrm{RH}: 2 / \mathrm{RH}: 4, \mathrm{RH}: 3 / \mathrm{RH}: 5$ variants have confirmed an association between $\mathrm{RH}: 2$ allele, thought to be under positive selection, and $\mathrm{RH}: 1$, this fact being generally seen in non-sub-Saharan populations [13].

The Duffy system profile (absence of Duffy «null » and marked predominance of FY : 2) is that of a zone in which there is no history of significant selective pressure regarding Plasmodium vivax malaria [23]. Thus, there seems to exist a positive correlation between FY :1 frequency and the exposure to this parasite among populations $[23,24]$. It is probable that drift has also contributed in the modification of $\mathrm{FY}: 1 / \mathrm{FY}: 2$ ratio in comparison with neighboring European populations [15]. 
When examining carefully the distribution of blood groups in the different Basque provinces one can evidence a significant degree of heterogeneity (tables 1-4) which has already noted for other markers such as plasma proteins polymorphism [25]. Distribution of $\mathrm{ABO}$ and $\mathrm{Rh}$ in the Basque area and also of other genetic markers divides this population in two groups: $1 /$ «tlantic» (in the north including provinces of Biscaye, Guipuzcoa, Labourd, BasseNavarre and Soule) and 2/ «Mediterranean» (in the south, Alava and Navarre), being separated by the watershed (fig. 1) [25]. The frequency of FY : 1 varies also according to provinces both in Hegoalde [25] and Iparralde [15]. The Mediterranean zone, being associated with less pronounced autochthonous genetic characteristics than the Atlantic one, represents a more open area (large plains) being conducive to population flows and therefore more favorable for mixing over the centuries (it houses the vast majority of Roman archeological sites located in the Basque territory). Other genetic subdivisions have been obtained within the Basque entity using molecular markers associated with a high degree of variability (STRs for instance) but the explanation regarding these population sub-units remains to be established [26].

\section{Medical consequences}

It is known for a long time that associations exist between the expression of some blood groups and the propensity to develop (or in contrary the protection against) some diseases. [27]. Individuals of group $\mathrm{O}$ express lower concentrations in circulating von Willebrand factor than non-O subjects [28]; therefore the lower limit for normality is inferior for $\mathrm{O}$ than for individuals of other groups [29]. Because of the high proportion of group $\mathrm{O}$ in Basques the diagnosis of von Willebrand disease is more challenging in this population, lot of cases being situated within the «grey zone »[30]. Amazingly, the Basques cumulate a series of particular biological characteristics with regards to hemostasis which offers a protective genetic profile against thrombosis : lower von Willebrand factor plasma levels, a more elevated prevalence 
of factor XI deficiency (about a 200-fold increase) related to a founder effect [31], a nearly absence of factor $\mathrm{V}$ Leiden (first predisposing genetic factor for venous thrombosis in Europeans) [32] and, probably, an inferior frequency of protein S deficiency [33]. Factor V Leiden is due to a single mutation and its high frequency encountered in Europe could be in relation with a selective advantage against (among others) hemorrhages especially within the obstetrical context [34]. A study performed from 1.5 million Scandinavian blood donors indicated that the fact of being of non-O group induced a significant over-risk for developing both venous and arterial thromboses (especially in case of pregnancy, relative risk: 2.2) [35]. It has been demonstrated that the expression of $\mathrm{O}$ represents one of the most protective genetic factors against the risk of cardiovascular diseases [36]. Of course, these disorders are influenced by other numerous intrinsic or extrinsic elements such as tobacco abuse, nutritional disequilibrium or lack of physical activity. The increased risk of coronary disease in non-O persons could be principally associated with higher LDL cholesterols levels [37]. Furthermore, according to a recent metaanalysis, group $\mathrm{O}$ individuals would be at minimal risk for developing type 2 diabetes [38]. It should be pointed out that the Spanish Basque provinces demonstrate actually the lowest prevalence of angor pectoris and an inferior frequency of diabetes, hypertension and dyslipidemia, in comparison with other regions of Spain [39]. We must take care not to confuse here a simplistic causal relationship considering the multiple underlying factors acting on the pathophysiology of these disorders. We haven't any specific data about French Basques who are not distinguishable from the other inhabitants of the département des Pyrénées Atlantiques. Likewise no study has been done on the epidemiology of venous thrombosis in order to know if it represents indeed a less frequent clinical entity in Basques [40]. There is in addition a very special Basque profile when assessing the expression of a panel of genes implicated in the pathophysiology of hemostasis («hemostaseome ») [41]. Thus, more differences between Basques and their neighbors from 
Aquitany are evidenced than between normal controls and patients with a history of thrombosis [41].

In the 1940's Etcheverry noticed in Argentina that many pregnancies among Basque women were complicated by severe hemolysis in newborns [9] because of the fetal maternal Rh immunization phenomenon. In 2017 at the centre hospitalier de la côte basque (CHCB) of Bayonne which includes the only public maternity of the French Basque Country, prophylactic injections of anti-RH:1 immunoglobulins were performed for 237 deliveries of RH:-1 women among a total of 2276 deliveries which represents $10.4 \%$ of the cases and $74.1 \%$ of the total consumption of anti-RH:1 immunoglobulins (data obtained from the CHCB pharmacy). In France, one estimate is that every year there are about 90000 pregnant RH : -1 women with a RH : 1 child for a total of 1.1 million conceptions (8.2\%) [42].

Finally, in the clinical transfusion practice, the relative high proportion of $\mathrm{O}$ RH :-1 packed red blood cells available in the Basque Country represents an interesting advantage in case of patients with unknown blood type needing emergency transfusions.

\section{Declaration of interests}

No conflict of interest to declare.

\section{Acknowledgements}

The author expresses his thanks to Dr Elisabeth Coudrin for the data about the use of antiRH:1 immunoglobulins. Research on Basque blood groups has been conducted with the help of association Sang 64. 


\section{References}

1 Cavalli-Sforza LL, Menozzi P, Piazza A. The history and geography of human genes. Princeton: Princeton University Press; 1994.

2 Aranzadi T, Barandiaran JM, Etcheverry MA. La raza vasca. Saint Sébastien : Aunamendi ; 1967.

3 Hirszfeld H, Hirszfeld L. Essai d'application des méthodes sérologiques au problème des races. L'Anthropologie $1919 ; 29$ : 505-537.

4 Bernard J, Ruffié J. Hématologie et culture. Le peuplement de l'Europe de l'Ouest. Ann Ecole Sci Prat Hautes Etud 1976 ; 4 : 661-676.

5 Boyd WC, Boyd LG. New data on blood groups and other inherited factors in Europe and Egypt. Am J Phys Antropol 1937; 23: 49-70.

6 Vallois HV. La répartition anthropologique des groupes sanguins en France et plus spécialement dans le sud-ouest. Bull Mém Soc Anthropol Paris 1944; 5: 53-80.

7 Mourant AE, Kopec AC, Domaniewska-Sobczak K. The distribution of the human blood groups. Oxford: Blackwell scientific publications; 1976.

8 Levine MH, von Hagen V, Ruffié J, Darrasse H. A hematological approach to Basque isolation in two French Basque villages. Ann NY Acad Sci 1977; 293: 185-193.

9 Etcheverry MA. El factor rhesus en genetic e importancia clinica. Diagn Med 1945; 17: $1237-1251$.

10 Touinssi M, Chiaroni J, Degioanni A, De Micco P, Dutour O, Bauduer F. Distribution of Rhesus (Rh) blood group system in the French Basques: a reappraisal using the allele-specific primers (ASP) PCR method. Hum Hered 2004; 58: 69-72. 
11 Weinstock C. It is worthwhile filling in the remaining blank spots for blood group antigen frequencies. Blood Transfus 2014; 12: 3-6.

12 Eweidah MH, Rahiman S, Ali MH, Al-Shamary AMD. Distribution of ABO and Rhesus (RHD) blood groups in Al-Jouf Province of the Saudi Arabia. Anthropologist 2011;13: 99102.

13 Flores-Bello A, Mas-Ponte D, Rosu ME, Bosch E, Calafell F, Comas D. Sequence diversity of the Rh blood system in Basques. Eur J Hum Genet 2018; Aug 8. doi: 10.1038/s41431-018-0232-1. [Epub ahead of print].

14 Van der Heide HM, Magnee W, Van Loghem JJ, Souchard L. Blood group distribution in Basques. Am J Hum Genet 1951; 3: 356-61.

15 Bauduer F, Touinssi M, Degioanni A, Leroux S, Dutour O, Ducout L, De Micco P, Chiaroni J. Duffy blood group genotyping in the French Basque population using polymerase chain reaction with allele-specific primers. Am J Hum Biol 2004; 16: 78-81.

16 Höher G, Fiegenbaum M, Almeida S. Molecular basis of the Duffy group system. Blood Transf 2018; 16: 93-100.

17 Touinssi M, Chiaroni J, Degioanni A, Granier T, Dutour O, Bailly P, Bauduer F. DNAbased typing of Kell, Kidd, MNS, Dombrock, Colton and Yt blood group systems in the French Basques. Am J Hum Biol 2008; 20: 308-311.

18 Moulinier J. The Rh factor in southwestern France; an examination of the Basque and Béarnais populations. Am J Phys Anthropol 1949; 7: 545-548.

19 Ruffié J. Etude séro-anthropologique des populations du versant nord des Pyrénées. Paris : Masson ; 1958. 
20 Bernard J, Ruffié J. Anthropologie de la France. Hématologie et culture. Le peuplement de l'Europe de l'ouest. Ann Ecole Sci Prat Hautes Etud 1976; 4 : 661-676.

21 Bauduer F, Degioanni A, Dutour O. Medical genetic as markers of evolutionary forces within the human genome: Hypotheses focusing on natural selection in the Basque population. Human Biol 2009; 81: 23-42.

22 Perry GH, Xue Y, Smith RS, Meyer WK, Caliscan M, Yanez-cuna O, Lee AS, GutierrezArcelus M, Ober C, Hollox EJ, Tyler-Smith C, Lee C. Evolutionary genetics of the human Rh blood group system. Hum Genet 2012; 131: 1205-1216.

23 King CL, Adams JH, Xianli J, Xianli J, Grimberg BT, et al. Fy Fy $^{\mathrm{b}}$ antigen polymorphism in human erythrocyte Duffy antigen affects susceptibility to Plasmodium vivax malaria. Proc Natl Acad Sci USA 2011; 108: 20113-20118.

24 Chittoria A, Mohanty S, Jaiswal YK, Das A. Natural Selection Mediated Association of the Duffy $(F Y)$ Gene Polymorphisms with Plasmodium vivax Malaria in India. PLoS One 2012 ; 7: e45219.

25 Manzano C, de la Rua C, Iriondo M, Mazon LI, Vicario A, Aguirre A. Structuring the genetic heterogeneity of the Basque population: a view from classical polymorphisms. Hum Biol 2002; 74: 51-74.

26 Iriondo M, Barbero MC, Manzano C. DNA polymorphisms detect ancient barriers to gene flow in Basques. Am J Phys Anthropol 2003 ; 122 : 73-84.

27 Anstee DJ. The relationship between blood groups and disease. Blood 2010; 115: 46354643.

28 O’Donnell J, Laffan MA. The relationship between ABO histo-blood group, factor VIII and von Willebrand factor. Transf Med 2001; 11: 343-351. 
29 Gill JC, Endres-Brooks J, Bauer PJ, Marks WJ, Montgomery RR. The effect of ABO blood group on the diagnosis of von Willebrand disease. Blood 1987; 69: 1691-1695.

30 Bauduer F, Ducout L. Is the assessment of von Willebrand disease prevalence an achievable challenge? The example of the French Basque Country where blood group $\mathrm{O}$ and factor XI deficiency are highly prevalent. J Thromb Haemost 2004; 2: 1724-1726.

31 Zivelin A, Bauduer F, Ducout L, Peretz H, Rosenberg N, Yatuv R, Seligsohn U. Factor XI deficiency in Basques is predominantly caused by an ancestral C38R mutation in the factor XI gene. Blood 2002; 99: 2448-2454.

32 Bauduer F, Zivelin A, Degioanni A, Ducout L, Dutour O, Shpringer E, Seligsohn U. The prevalence of factor V G1691A in French Basques, but not of prothrombin G20210A and methylenetetrahydrofolate reductase C677T, is remarkably low. J Thromb Haemost 2004; 2: 361-362.

33 Bauduer F. Protein S deficiency in patients from the French Basque Country with various thrombotic conditions: a rarer inherited trait in autochthonous individuals? J Thromb Thrombol 2018; 46: 244-245.

34 Lindqvist PG, Dahlbäck B. Carriership of Factor V Leiden and evolutionary selection advantage. Curr Med Chemistr 2008; 15: 1541-1544.

35 Vasan SK, Rostgaard K, Majeed A, Ullum H, Titlestad KE, Pedersen OB, Erikstrup C, Nielsen KR, Melbye M, Nyrén O, Hjalgrim H, Edgren G. ABO blood group and risk of thromboembolic and arterial disease: a study of 1.5 million blood donors. Circulation 2016; 133: $1449-57$.

36 Franchini M, Mannucci PM. ABO blood group and thrombotic vascular disease. Thromb Haemost 2014; 112: 1103-1109. 
37 Chen Y, Chen C, Ke X, Xiong L, Shi Y, Li J, Tan X, Ye S. Analysis of circulating cholesterol Llevels as a mediator of an association between ABO blood group and coronary heart disease. Circ Cardiovasc Genet 2014; 7: 43-48.

38 Meo SA, Rouq FA, Suraya F, Zaidi SZ. Association of ABO and Rh blood groups with type 2 diabetes mellitus. Eur Rev Med Pharmacol Sci 2016; 20: 237-242.

39 López-Bescós L, Cosín J, Elosua R, Cabadés A, De los Reyes M, Arós F, et al. Prevalencia de angina y factores de riesgo cardiovascular en las diferentes comunidades autónomas de España: estudio PANES. Rev Esp Cardiol 1999; 52: 1045-56.

40 Bauduer F. Is there a significant lower genetic susceptibility to venous thrombosis in the Basques? Blood Coagul Fibrinol 2014; 25: 645-647.

41 Freyburger G, Labrouche S, Hubert C, Bauduer F. Haemostaseome-associated SNPs: has the thrombotic phenotype a greater influence than ethnicity? GMT study from Aquitaine including Basque individuals. Thromb Haemost 2015; 113: 66-76.

42 Détermination prénatale du genotype $R H D$ fœtal à partir du sang maternel. Haute Autorité de Santé ; 2011.

43 Chalmers JNM, Ikin EW, Mourant AE. The ABO, MN and Rh blood groups of the Basque people. Am J Phys Anthropol 1949;7: 529-544.

44 Nijenhuis LE. Blood group frequencies in French Basques. Hum Hered 1956 ;6: 531-535. 45 Alberdi F, Allison AC, Blumberg BS, Ikin EW, Mourant AE. The blood groups of the Spanish Basques. J R Anthropol Inst 1957; 87: 217-221.

46 Manzano C, Orue JM, de la Rua C. The "Basqueness" of the Basques of Alava: a reappraisal from a multidisciplinary perspective. Am J Phys Anthropol 1996; 99: 249-258. 
47 Manzano C, Aguirre AI, Iriondo M, Martin M, Osaba L, de la Rua C. Genetic polymorphisms of the Basques from Gipuzkoa: genetic heterogeneity of the Basque population. Ann Hum Biol 1996; 23: 285-296.

48 Guasch J. El factor Rh en España. Rev Esp Pediatr 1950; 6: 387-390.

49 Daniels G. Human blood groups. Oxford: Blackwell Science; 1995. 
Fig.1 The seven provinces of the extant Basque Country (localities in italics are mentioned within the text or tables)

The black thick line represents the watershed separating the so-called Atlantic (north) and Mediterranean (south) zones. 
Table 1. ABO blood group frequencies in Basques (\%) according to the main published series

\begin{tabular}{|c|c|c|c|c|c|}
\hline $1^{\text {st }}$ author, year, place & $\mathbf{n}$ & $\mathbf{A}$ & B & $\mathbf{A B}$ & $\mathbf{O}$ \\
\hline Boyd, 1937, Saint Sébastien area [5] & 229 & 39,7 & 1,3 & 2,2 & 56,8 \\
\hline $\begin{array}{l}\text { Etcheverry, 1945, Buenos Aires, } \\
\text { Argentine [9] }\end{array}$ & 250 & 40,8 & 2,8 & 0,4 & 56 \\
\hline Moulinier, 1949, Iparralde [18] & 516 & 38,4 & 2,7 & 0,9 & 57,9 \\
\hline Labourd & 68 & 36,8 & 5,9 & 0 & 57,3 \\
\hline Basse Navarre & 233 & 39,5 & 2,1 & 0 & 58,4 \\
\hline Soule & 215 & 37,7 & 2,3 & 2,3 & 57,7 \\
\hline Chalmers, 1949, Saint Sébastien [43] & 383 & $\begin{array}{c}43,6 \\
\text { A1 : } 37,3 \\
\text { A2 : } 6,3\end{array}$ & 4,2 & 1,0 & 51,2 \\
\hline Van der Heide, 1951, Biarritz [14] & 181 & 43,0 & 3,3 & 1,6 & 51,9 \\
\hline Nijenhuis, 1956, Iparralde [44] & 484 & 40,5 & 0,8 & 0,4 & 58,3 \\
\hline Alberdi, 1957, Navarre and Guipuzcoa & 161 & 37,8 & 5,0 & 1,9 & 55,3 \\
\hline
\end{tabular}




\begin{tabular}{|c|c|c|c|c|c|}
\hline [45] & & $\begin{array}{l}\text { A1 : } 33,5 \\
\text { A2 : 4,3 }\end{array}$ & & & \\
\hline Levine, 1977 [8] & 701 & 39,7 & 2,3 & 0,8 & 57,2 \\
\hline Ahetze & 319 & 43,6 & & & \\
\hline Macaye & 382 & 35,2 & & & \\
\hline Manzano, 1996, Alava [46] & 480 & 48,8 & 1,5 & 1,0 & 49,0 \\
\hline Manzano, 1996, Guipuzcoa [47] & 586 & $\begin{array}{c}39,9 \\
\text { A1 : } 210 \\
\text { A2 : } 24\end{array}$ & 3,9 & 0,7 & 55,4 \\
\hline
\end{tabular}

$\mathrm{n}$ denotes the number of individuals.

In France the ABO profile is the following ( $\mathrm{n}=6236)$ : $\mathrm{A}: 45,3 \%, \mathrm{~B}: 6,4 \%, \mathrm{AB}: 2,2 \%, \mathrm{O}$ : $46,1 \%[6]$ 
Table 2. Percentage of $\mathrm{RH}:-1$ phénotype («Rh negative») in various samples of Basque individuals

\begin{tabular}{|c|c|c|c|}
\hline References & Place & $\mathbf{n}$ & RH:-1 \\
\hline Etcheverry, 1945 [9] & Argentine & 250 & $89(35,6 \%)$ \\
\hline Moulinier, 1949 [18] & France ( 3 provinces) & 516 & $126(24,4 \%)$ \\
\hline Chalmers, 1949 [43] & France & 383 & $112(29,2 \%)$ \\
\hline Nijenhuis, $1956^{1}[44]$ & France (Biarritz) & 482 & $99(20,5 \%)$ \\
\hline Alberdi, 1957 [45] & Guipuzcoa and Navarre & 161 & $36(22,3 \%)$ \\
\hline Levine, 1977 [8] & Ahetze and Macaye & 706 & $181(25,6 \%)$ \\
\hline Manzano, 1996 [46] & Alava & 480 & $104(21,6 \%)$ \\
\hline Manzano, 1996 [47] & Guipuzcoa & 586 & $162(27,6 \%)$ \\
\hline Touinssi , $2005^{2}[10]$ & France (3 provinces) & 126 & $36(28,5 \%)$ \\
\hline Flores-Bello, $2018^{2}$ [13] & Not reported & 53 & $12(22,2 \%)$ \\
\hline
\end{tabular}

${ }^{1}$ this « surprising » result is in relation with the selection criterion : individuals from Biarritz whatever their origin; ${ }^{2}$ data obtained using molecular biology; $\mathrm{n}$ denotes the number of individuals. In Europe the mean frequency of RH :-1 phenotype is $16 \%$ [7] 
Table 3. Distribution of Rh haplotypes frequency (\%) among various Basque populations and in an English sample as control

\begin{tabular}{|c|c|c|c|c|c|c|c|c|}
\hline Rh haplotypes & $\begin{array}{c}\text { Chalmers } \\
\text { et al, } 1949 \\
{[43]} \\
\mathrm{N}=383\end{array}$ & $\begin{array}{c}\text { Guasch et } \\
\text { al, } 1950 \\
\text { [48] } \\
\mathrm{N}=626\end{array}$ & $\begin{array}{c}\text { Alberdi et } \\
\text { al, } 1957 \\
{[45]} \\
\text { Guipuzcoa } \\
\text { and } \\
\text { Navarre } \\
\text { N=161 }\end{array}$ & $\begin{array}{c}\text { Manzano } \\
\text { et al, 1996, } \\
\text { [47] } \\
\text { Guipuzcoa } \\
\text { N=586 }\end{array}$ & $\begin{array}{c}\text { Manzano } \\
\text { et al, 1996, } \\
\text { [46] } \\
\text { Alava } \\
\text { N=480 }\end{array}$ & $\begin{array}{l}\text { Touinssi et } \\
\text { al, 2008* } \\
{[10]} \\
\text { Iparralde } \\
\mathrm{N}=126\end{array}$ & $\begin{array}{c}\text { Flores-Bello } \\
\text { et al, 2018* } \\
\qquad 13] \\
\mathrm{N}=53\end{array}$ & $\begin{array}{c}\text { England } \\
\text { [49] } \\
\mathrm{N}=2000\end{array}$ \\
\hline $\begin{array}{c}R H 1,2,3,-4,-5 \\
(C D E)\end{array}$ & NR & 1,43 & NR & 3,95 & 0,02 & 1,2 & 0,0 & 0,24 \\
\hline $\begin{array}{c}R H 1,2,-3,-4,5 \\
(C d e)\end{array}$ & 37,67 & 40,32 & 43,72 & 35,8 & 36,97 & 37,9 & 38,5 & 42,05 \\
\hline $\begin{array}{c}R H-1,2,-3,-4,5 \\
(C d e)\end{array}$ & 1,37 & 2,71 & 1,94 & 2,11 & 1,10 & 3,8 & 4,7 & 0,98 \\
\hline $\begin{array}{c}R H 1,-2,3,4,-5 \\
(c D E)\end{array}$ & 6,83 & 4,31 & 9,01 & 3,13 & 12,38 & 7,3 & 9,1 & 14,11 \\
\hline $\begin{array}{c}R H 1,-2,-3,4,5 \\
(c D e)\end{array}$ & NR & 7,26 & NR & 1,17 & 3,41 & 2,5 & 5,3 & 2,57 \\
\hline $\begin{array}{c}R H-1,-2,3,4,-5 \\
(c d E)\end{array}$ & 0,24 & 0,35 & NR & 0,48 & 0,41 & 1,7 & 0,9 & 1,19 \\
\hline $\begin{array}{c}R H-1,-2,-3,4,5 \\
\text { (cde) }\end{array}$ & 53,15 & 43,62 & 44,69 & 53,36 & 45,72 & 45,6 & 41,5 & 38,86 \\
\hline
\end{tabular}

NR: not reported; *data obtained using molecular biology; $\mathrm{N}$ denotes the number of individuals 
Tableau 4. Distribution of allele frequencies in blood group systems except $\mathrm{ABO}$ and $\mathrm{Rh}$ in various Basque samples and comparison with results obtained in other European populations

\begin{tabular}{|c|c|c|c|c|}
\hline System & $\begin{array}{c}\text { Allele/haplotype } \\
\text { frequency }\end{array}$ & Place & $\begin{array}{c}\mathbf{1}^{\text {st }} \text { author (year) } \\
\text { [reference] }\end{array}$ & $\begin{array}{l}\text { Allele frequencies } \\
\text { in Europe }\end{array}$ \\
\hline \multirow[t]{4}{*}{ Kell } & $\begin{array}{l}K E L: 1: 0,0264 \\
K E L: 2: 0,9736\end{array}$ & Macaye (Labourd) & $\begin{array}{c}\text { Levine (1977) } \\
{[8]}\end{array}$ & \multirow{4}{*}{$\begin{array}{c}K E L: 1: 0,0902 \\
K E L: 2: 0,9098 \\
\text { (English) [49] }\end{array}$} \\
\hline & $\begin{array}{l}K E L: 1: 0,0204 \\
K E L: 2: 0,9796\end{array}$ & Ahetze (Labourd) & $\begin{array}{c}\text { Levine (1977) } \\
{[8]}\end{array}$ & \\
\hline & $\begin{array}{l}\text { KEL :1 : 0,0299 } \\
K E L: 2: 0,9701\end{array}$ & Guipuzcoa & $\begin{array}{c}\text { Manzano (1996) } \\
{[47]}\end{array}$ & \\
\hline & $\begin{array}{l}\text { KEL :1 :0,075 } \\
K E L: 2: 0,925\end{array}$ & Iparralde & $\begin{array}{c}\text { Touinssi }(2008)^{*} \\
{[17]}\end{array}$ & \\
\hline \multirow[t]{3}{*}{ Kidd } & $\begin{array}{l}J K: 1: 0,5713 \\
J K: 2: 0,4287\end{array}$ & Macaye (Labourd) & $\begin{array}{c}\text { Levine (1977) } \\
{[8]}\end{array}$ & \multirow{3}{*}{$\begin{array}{c}J K: 1: 0,5142 \\
J K: 2: 0,4858 \\
\text { (mixing of } \\
\text { Europeans) [49] }\end{array}$} \\
\hline & $\begin{array}{l}J K: 1: 0,5077 \\
J K: 2: 0,4923\end{array}$ & Ahetze (Labourd) & $\begin{array}{c}\text { Levine (1977) } \\
{[8]}\end{array}$ & \\
\hline & $\begin{array}{l}J K: 1: 0,566 \\
J K: 2: 0,434\end{array}$ & Iparralde & $\begin{array}{c}\text { Touinssi }(2008)^{*} \\
{[17]}\end{array}$ & \\
\hline \multirow[t]{3}{*}{ Duffy } & $F Y: 1: 0,35$ & Iparralde & $\begin{array}{c}\text { Nijenhuis (1956) } \\
{[44]}\end{array}$ & \multirow[t]{3}{*}{$\begin{array}{c}F Y: 1: 0,398 \\
\text { (Europeans) [16] }\end{array}$} \\
\hline & $F Y: 1: 0,30$ & $\begin{array}{c}\text { Guipuzcoa and } \\
\text { Navarre }\end{array}$ & $\begin{array}{c}\text { Alberdi (1957) } \\
\text { [45] }\end{array}$ & \\
\hline & $F Y: 1: 0,31$ & Macaye (Labourd) & Levine (1977) & \\
\hline
\end{tabular}




\begin{tabular}{|c|c|c|c|c|}
\hline & & & [8] & \\
\hline & $F Y: 1: 0,34$ & Ahetze (Labourd) & Jevine (1977) & \\
\hline & & & [8] & \\
\hline & $F Y: 1: 0,38$ & Alava & Manzano (1996) & \\
\hline & & & [46] & \\
\hline & $F Y: 1: 0,35$ & Guipuzcoa & Manzano (1996) & \\
\hline & & & [47] & \\
\hline & $F Y: 1: 0,32-$ & Guipuzcoa & Manzano (2002) & \\
\hline & $0,40 \S$ & (4 districts) & [25] & \\
\hline & $F Y: 1: 0,32$ & Iparralde & Bauduer (2004)* & \\
\hline & & & {$[15]$} & \\
\hline MNS & $M: 0,5443$ & Macaye (Labourd) & Levine (1977) & \\
\hline & $N: 0,4557$ & & {$[8]$} & \\
\hline & $S: 0,6181$ & & & \\
\hline & $s: 0,4242$ & & & \\
\hline & $M: 0,6118$ & Ahetze (Labourd) & Levine (1977) & \\
\hline & $N: 0,3882$ & & [8] & \\
\hline & $S: 0,5758$ & & & \\
\hline & $s: 0,3819$ & & & \\
\hline & $M S: 0,2740$ & Alava & Manzano (1996) & $M S: 0,2472$ \\
\hline & $M s: 0,2708$ & & [46] & $M s: 0,2831$ \\
\hline & $N S: 0,0896$ & & & $N S: 0,0802$ \\
\hline & $N s: 0,3656$ & & & $N s: 0,3895$ \\
\hline & $M S: 0,2750$ & Guipuzcoa & Manzano (1996) & (English) [49] \\
\hline & $M s: 0,2847$ & & [47] & \\
\hline
\end{tabular}




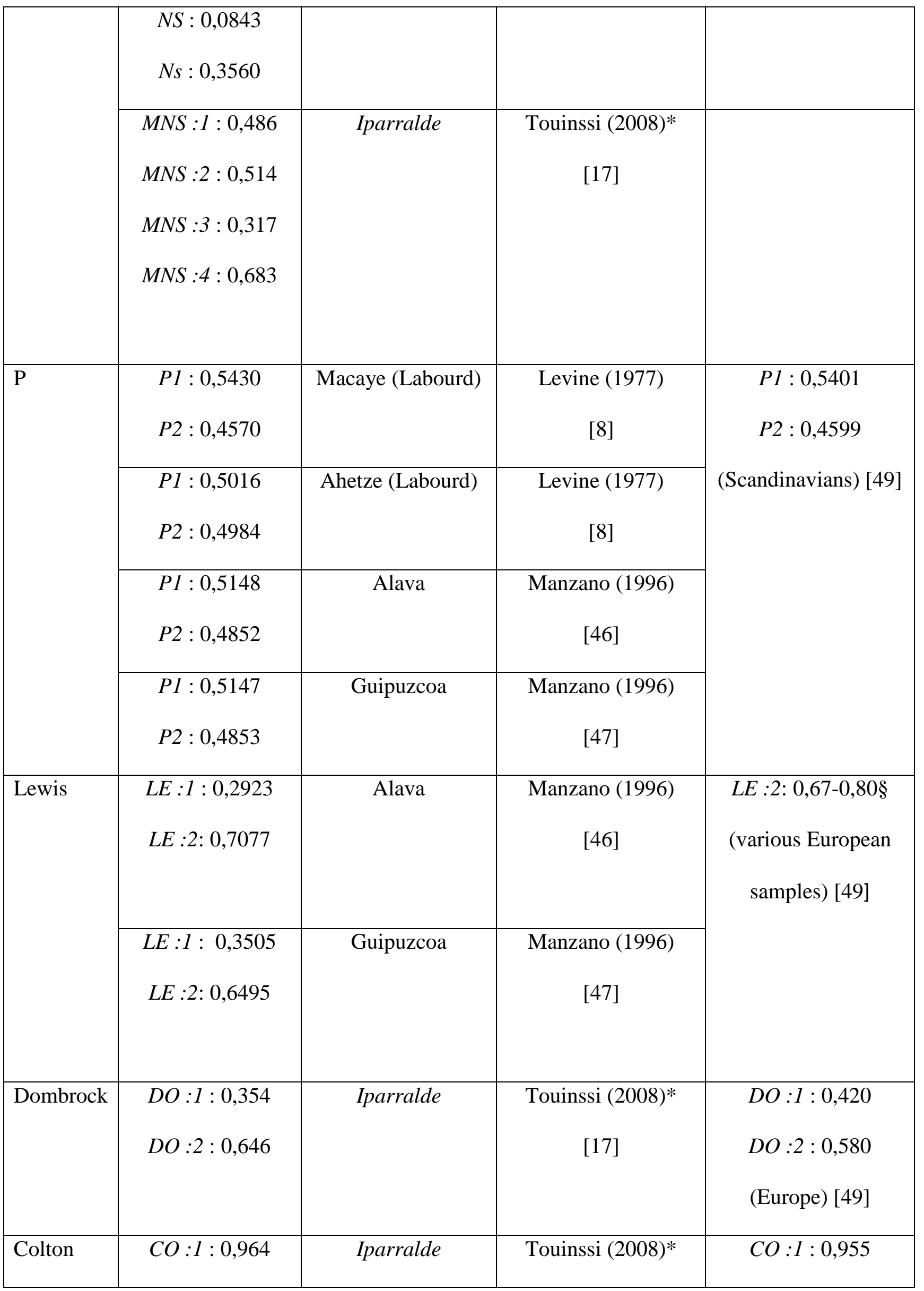




\begin{tabular}{|c|c|c|c|c|}
\hline & $C O: 2: 0,036$ & & [17] & $\begin{array}{l}C O: 2: 0,045 \\
\text { (Europe) [49] }\end{array}$ \\
\hline YT & $\begin{array}{l}Y T: 1: 0,964 \\
Y T: 2: 0,036\end{array}$ & Iparralde & $\begin{array}{c}\text { Touinssi }(2008) * \\
{[17]}\end{array}$ & $\begin{array}{c}Y T: 1: 0,955-0,976 \S \\
Y T: 2: 0,024-0,045 \S \\
\quad \text { (Europe) [49] }\end{array}$ \\
\hline
\end{tabular}

*data obtained using PCR, § range, $\mathrm{N}$ denotes the number of individuals 


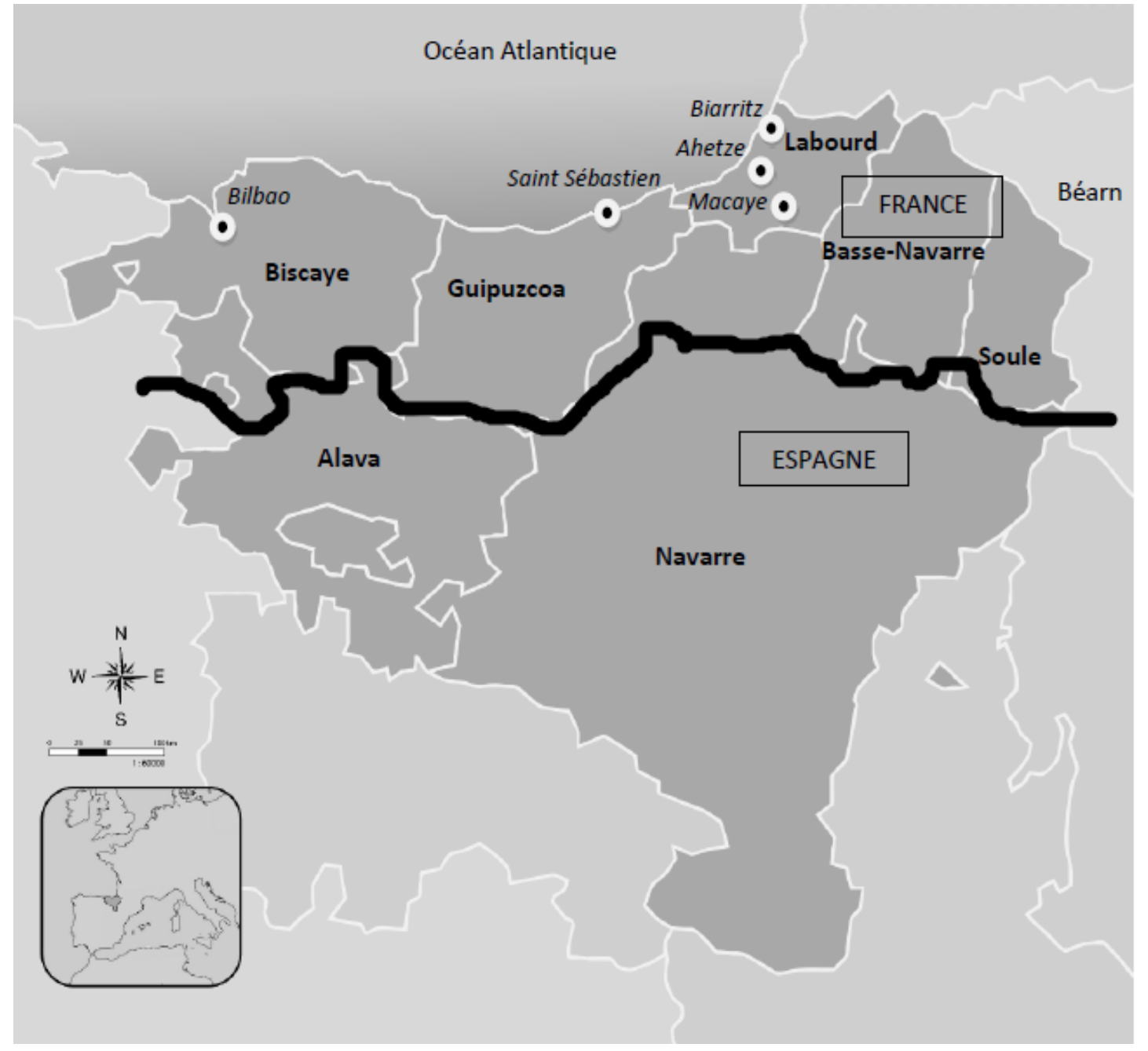

